\section{Australian Journal of \\ Crop Science}

AJCS

ISSN:1835-2707

AJCS 14(03):447-454 (2020)

doi: 10.21475/ajcs.20.14.03.p1986

\title{
Managing the number of orthotropic stems in Coffea arabica as strategy for cultivation at low-altitude regions
}

\section{Tafarel Victor Colodetti ${ }^{1 *}$, Wagner Nunes Rodrigues ${ }^{1}$, Paulo Cezar Cavatte ${ }^{3}$, Edvaldo Fialho dos Reis ${ }^{4}$, Abraão Carlos Verdin Filho ${ }^{5}$, Sebastião Vinícius Batista Brinate ${ }^{1}$, Lima Deleon Martins ${ }^{1}$, Bruno Fardim Christo $^{1}$, Saul de Andrade Júnior ${ }^{1}$, Marcelo Antonio Tomaz ${ }^{2}$}

\author{
${ }^{1}$ Programa de Pós-Graduação em Produção Vegetal, Centro de Ciências Agrárias e Engenharias da Universidade \\ Federal do Espírito Santo (CCAE-UFES), Alegre, ES, Brazil \\ ${ }^{2}$ Professor do Departamento de Agronomia, Centro de Ciências Agrárias e Engenharias da Universidade Federal do \\ Espírito Santo (CCAE-UFES), Alegre, ES, Brazil \\ ${ }^{3}$ Professor do Departamento de Biologia, Centro de Ciências Agrárias e Engenharias da Universidade Federal do \\ Espírito Santo (CCAE-UFES), Alegre, ES, Brazil \\ ${ }^{4}$ Professor do Departamento de Engenharia Rural, Centro de Ciências Agrárias e Engenharias da Universidade \\ Federal do Espírito Santo (CCAE-UFES), Alegre, ES, Brazil \\ ${ }^{5}$ Pesquisador do Instituto Capixaba de Pesquisa, Assistência Técnica e Extensão Rural, Fazenda Experimental do \\ INCAPER, Marilândia, ES, Brazil
}

*Corresponding author: tafarelcolodetti@hotmail.com

\begin{abstract}
The objective of this study was to better understand the implications of the management of the number of orthotropic stems in Arabica coffee for its cultivation in low-altitude regions $(<500 \mathrm{~m})$, characterizing its effects over the canopy architecture, production and allocation of biomass, photosynthesis and crop yield, as possible strategy for mitigating the stresses of cultivation at low-altitude regions. The experiment was conducted in a region with $124 \mathrm{~m}$ of elevation above sea level, studying four treatments with different numbers of orthotropic stems per plant such as one, two, three and four stems. After planting, during the stage of sprout budding, a number of sprouts were established in accordance to the treatments. The experimental design was a randomized block design, with eight repetitions. Parameters of gas exchange, chlorophyll contents, canopy architecture, production and allocation of biomass, and crop yield were evaluated to characterize the plant development. Overall, increasing the number of orthotropic stems per plant promoted leaf density, number of plagiotropic branches per plant, available leaf area per fruit mass, photosynthetic rate, crop yield, proportion of large grains and, possibly, the de-acceleration of the stem aging rate, mainly for the management with four orthotropic stems. It is concluded that the management of the number of orthotropic stems has potential use as a mitigator for the cultivation of Arabica coffee in low-altitude regions, being able to promote higher canopy density and, possibly, enhance microclimate conditions at the canopy level.
\end{abstract}

Keywords: Arabica coffee; crop yield; microclimate; mitigation; stress.

Abloreviations: $A_{-} \mathrm{CO}_{2}$ assimilation rate; $\mathrm{ANG}$ insertion angle of the plagiotropic branches in the orthotropic stem; $\mathrm{CHL}$ chlorophyll content; Ci_sub-stomatal concentration of $\mathrm{CO}_{2}$; $\mathrm{CPP}$ _total mass of processed coffee per plant; CPS_production of processed coffee per orthotropic stem; DEN_leafage density; DMF_dry mass of fruits; DML_dry mass of leaves; DMS_dry mass of stem; E_transpiration rate; FMR_fruit mass ratio; $g_{s_{-}}$stomatal conductance; Leaf/Fruit_ratio between the total leaf area and the mass of fruits of the plagiotropic branch; LMR_leaf mass ratio; LPB_length of the plagiotropic branches; NPB_total number of plagiotropic branches per plant; PLH_plant height; SMR_stem mass ratio; TDM_total dry mass of the plagiotropic branch; ULA_unitary leaf area.

\section{Introduction}

Global studies have indicated severe losses and changes in areas considered suitable for growing coffee in South and Central America, mainly due to the projected scenarios of increased air temperature caused by climate change (Bunn et al., 2015). In addition, studies have been pointing to the possibility of numerous modifications in the plant development being caused by changes in environmental concentrations of $\mathrm{CO}_{2}$ (Ainsworth and Rogers, 2007). Scenarios climate change have been related to cause modifications in the regions suitable to cultivation coffee worldwide (Lane and Jarvis, 2007; Titus and Pereira, 2008; Camargo, 2010; Jaramillo et al., 2011; Davis et al., 2012; Rahn et al., 2013), as well as estimating a possible $15 \%$ decrease in the world's coffee-growing area for the next 50 
years (Lane and Jarvis, 2007).

In Brazil, some scenarios even discuss the possibility of a drastic decrease or even eradication of areas traditionally cultivated with Arabica coffee (Coffea arabica Lineu) (Camargo, 2010), in the northwest of the state of São Paulo and in the south of the state of Minas Gerais, as result of the temperature increases in the last decades. In general, these changes may be responsible not only for the decrease of areas considered suitable for cultivation of Arabica coffee, but also may cause the displacement to regions of different altitudes (Assad et al., 2004).

In this context of climatic changes, there is a current need for studies to evaluate alternatives to adapt and change management techniques, aiming to allow the sustained cultivation of coffee in regions where climatic conditions have been classified as marginal or inept for this agricultural activity.

Important considerations should be raised regarding the effects of pruning on coffee plants, since the ability to change the source-drain relation of carbohydrates acts directly on the canopy renewal and, therefore, on the photosynthetic apparatus of the whole plant (Pereira et al., 2013), besides favoring the development of the coffee root system (Alves et al., 2011). If used correctly, pruning favors the formation of new branches and leaves, which will directly impact the metabolism of the plant and help stablishing control over the growth rate, through the increased luminosity and air flow inside the plant canopy (Sartori et al., 2007).

Studies about the yield of Arabica coffee have been showing that growing plants with more orthotropic stems, proceeding the removal of plagiotropic branches that already produced $70 \%$ of their capacity, resulted in greater gains in production per area (Colodetti et al., 2018; Verdin Filho et al., 2016). This new pruning management for Arabica coffee maybe be an alternative for cultivation in regions of low altitude, acting as a strategy to mitigate some climatic stresses through the modulation of microclimatic conditions, caused by the thickening of the canopy system in the plantation.

The densification acts as a mitigation strategy for climate vulnerability (Rahn et al., 2013); in coffee, it promotes an increase in plant coverage and generates microclimatic changes in the plantation (DaMatta et al., 2007). Thus, it is suggested that the increase in the number of orthotropic stems per plant acts as a form of densification and, therefore, may become an alternative to be used as mitigation strategy to some environmental stresses. However, it is necessary to know the limits of densification of coffee plants, in order to avoid problems of excessive selfshading and photosynthetic constraints (DaMatta et al., 2007).

In this context, the objective of this study was to better understand the effects of the management of the number of orthotropic stems per plant of Arabica coffee, and the possibility of being used as a strategy to mitigate the stresses of cultivation at low-altitude regions.

\section{Results}

\section{Canopy architecture}

The characteristics of the canopy and growth of plagiotropic branches of the Arabica coffee in low altitude were influenced by the management of orthotropic stems (Figure 1). The plant height differed significantly between plants with one and two stems (Figure 1A), while the number of plagiotropic branches differed among all treatments, with higher numbers in plants with four vertical stems and lower in plants with only one orthotropic stem (Figure 1B). However, the internal angle formed between these stems and the vertical stem did not change due to the increase in the number of orthotropic stems per plant (Figure 1D). As for the unitary leaf area, it was observed larger area in the plants managed with two stems and smaller in the plants with four orthotropic stems (Figure 1E).

The leafage density differed significantly among treatments with different numbers of orthotropic stems, where plants managed with four stems presented the highest density and plants with one stem presented the lowest leafage density (Figure 1F). Pearson correlation analysis showed the existence of positive and significant relationship between DEN and NPB $\left(r=0.99^{* *}\right)$, indicating that the increase in NPB contributed to the increase in leafage density. In addition, the measurement of NPB is relatively simple and fast, and expresses strong correlation with DEN.

The DEN outlines the general aspects of the conformation of the coffee canopy as function of the management of orthotropic stems that was adopted. It is worth mentioning that DEN is directly related to the area and the volume of the canopy, and thus, the increase in the number of orthotropic stems promoted larger canopy areas and volumes for the plants of Arabica coffee in low-altitude region.

\section{Biomass production and allocation in the plagiotropic branches}

The production and partition of biomass among the structures of the plagiotropic branches were also significantly influenced by the management of orthotropic stems (Figure 2). The highest productions of total dry matter of plagiotropic branches were obtained in the management with only one orthotropic stem, sequentially followed by the managements with two and four stems. For three orthotropic stems per plant, the lowest MST production was obtained (Figure 2A).

Plants with three or four orthotropic stems presented their plagiotropic branches with higher stem mass ratios than plants with two vertical branches (Figure 2B), also presented greater leaf mass ratios (Figure $2 \mathrm{C}$ ) and lower fruit mass ratios (Figure 2D).

The relationship between the leaf area of the plagiotropic branch and the biomass of their fruits was significantly different, where the management with three and four orthotropic stems provided greater leaf areas to sustain the production of one gram of fruit, while smaller leaf/fruit ratios were observed for plants with one and two orthotropic stems (Figure 2E).

The ratio of available leaf area per fruit mass was positively and significantly correlated with NPB $\left(r=0.96^{*}\right)$, which indicates a strong interaction of this variable with a morphological characteristic which is easier to measure.

\section{Gas exchanges and chlorophyll}

The analysis of gas exchanges and chlorophyll content showed significant differences as response to the number of 

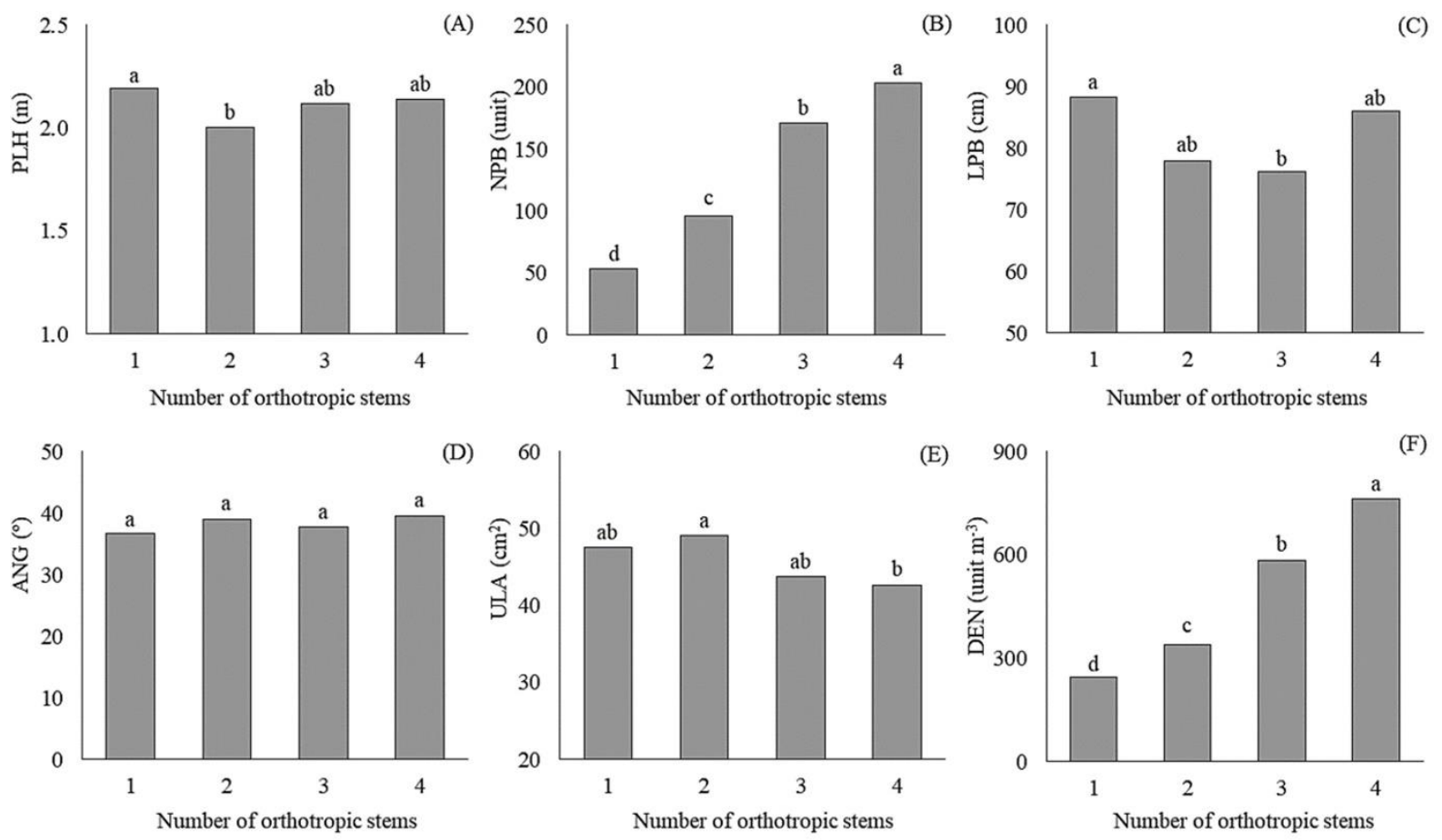

Fig 1. Plant height (A), number of plagiotropic branches (B), length of plagiotropic branches (C), insertion angle of plagiotropic branches (D), unitary leaf area (E) and leafage density (F) as response to the number of orthotropic stems per plant of Arabica coffee (Obatã), in low-altitude region. Means followed by the same letter do not differ from each other (Tukey test, $p \leq 0.05)$.

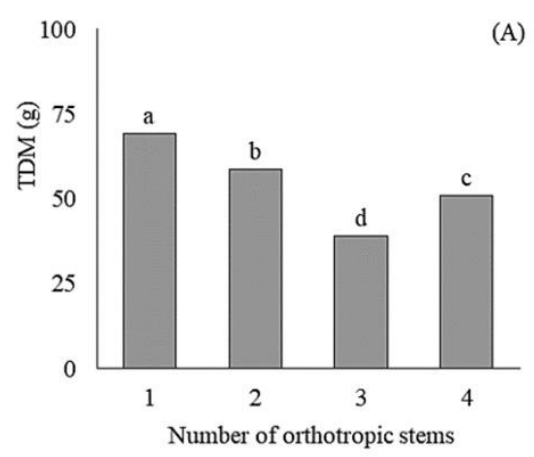

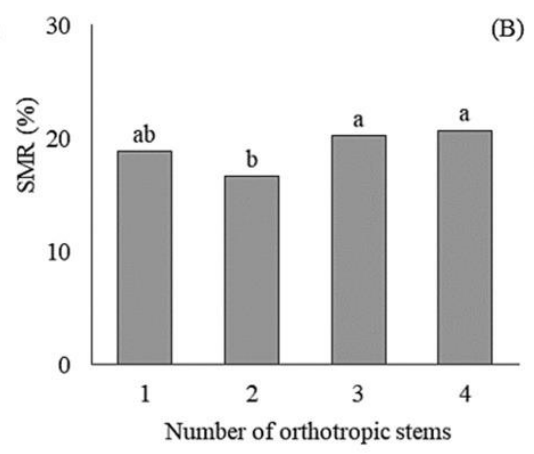

(D)

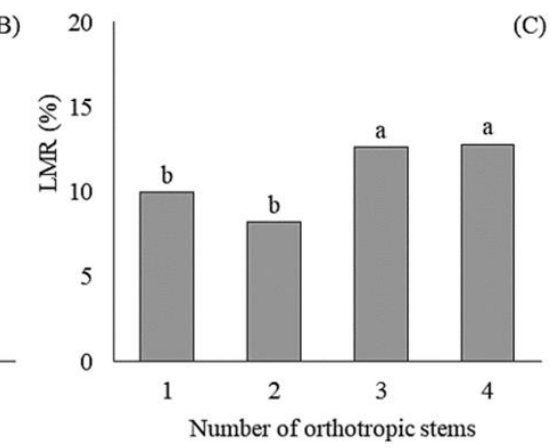

(E)
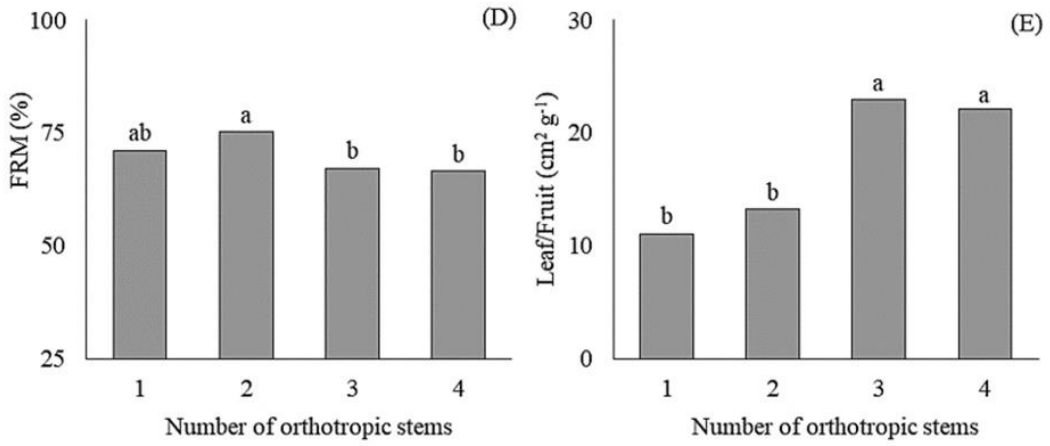

Fig 2. Total dry matter (A), stem mass ratio (B), leaf mass ratio (C), fruit mass ratio (D), available leaf area per fruit mass (E) of the plagiotropic branches as response to the number of orthotropic stems per plant of Arabica coffee (Obatã), in low-altitude region. Means followed by the same letter do not differ from each other (Tukey test, $p \leq 0.05$ ). 

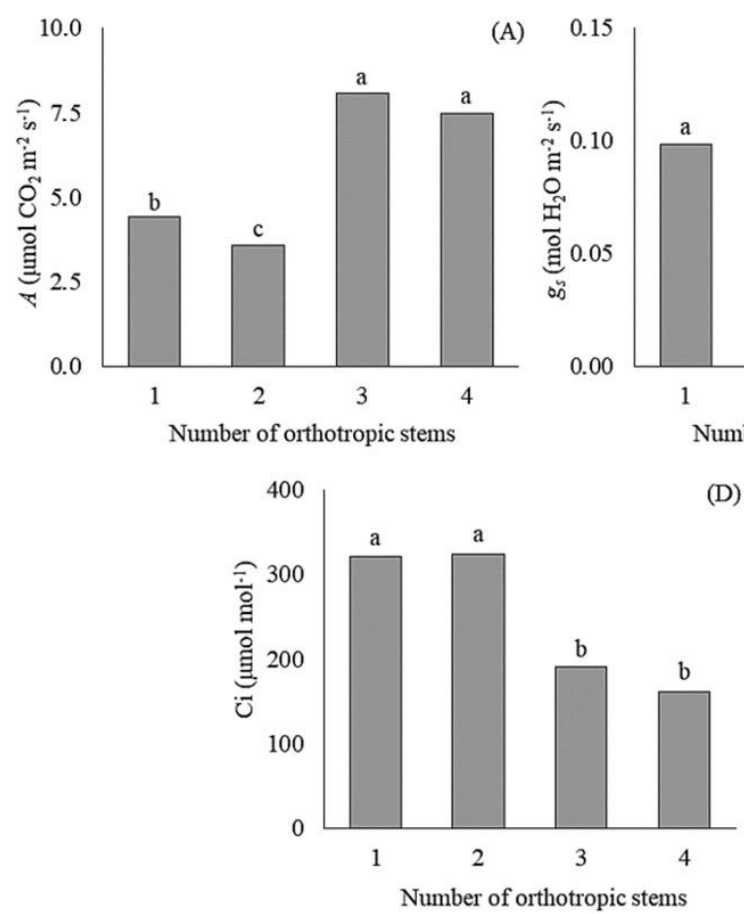

(B)

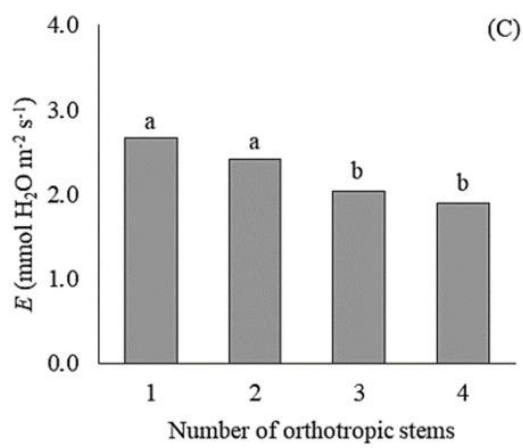

(E)

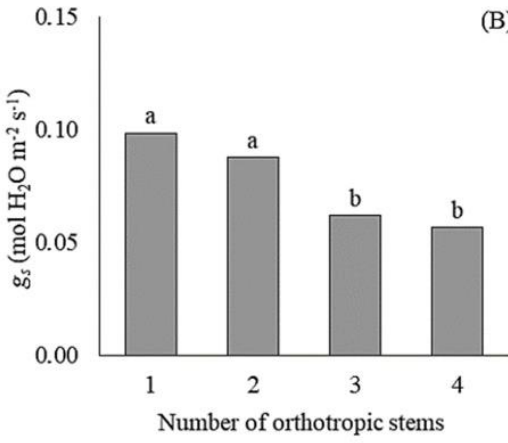

(D)

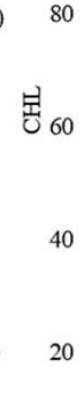

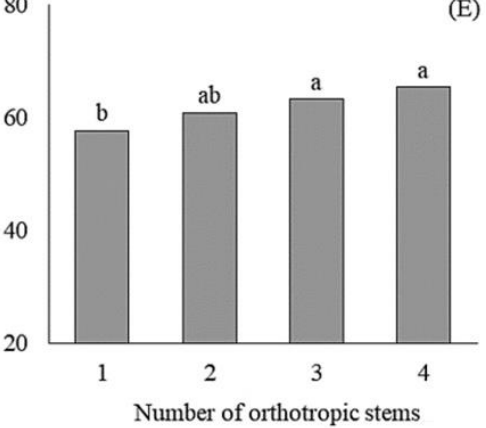

Fig 3. Net assimilation of $\mathrm{CO}_{2}(A)$, stomatal conductance (B), transpiration rate (C), sub-stomatal concentration of $\mathrm{CO}_{2}(\mathrm{D})$ and total chlorophyll content (E) as response to the number of orthotropic stems per plant of Arabica coffee (Obatã), in low-altitude region. Means followed by the same letter do not differ from each other (Tukey test, $p \leq 0.05$ ).
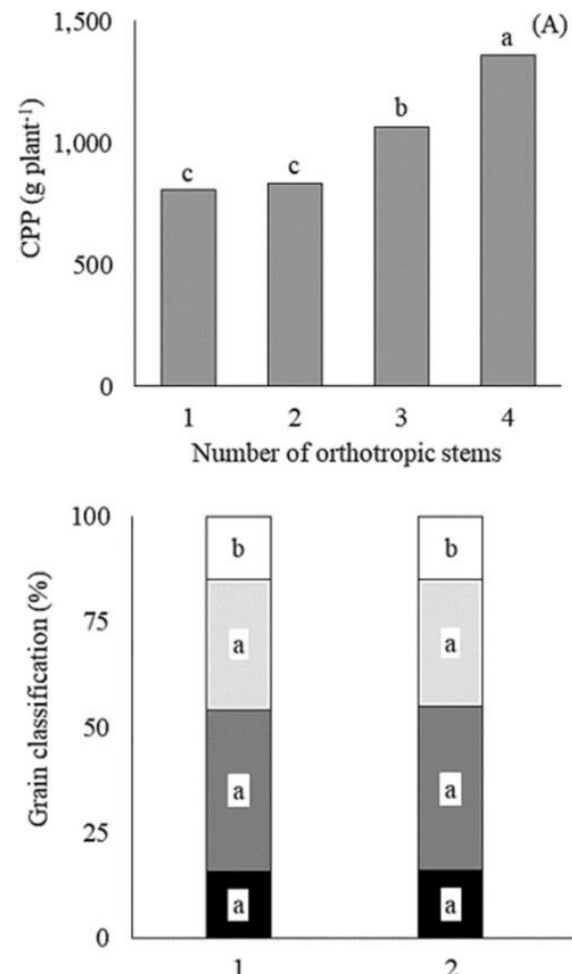

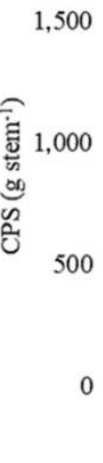

0 ب 1
(B)

(C)

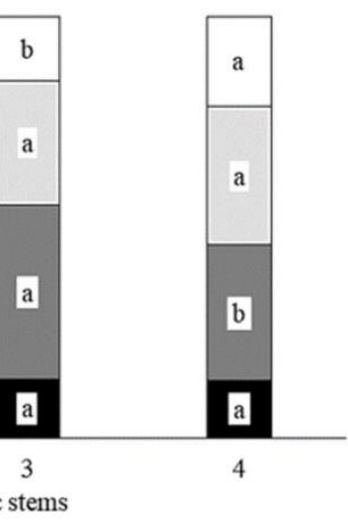

(C)

Fig 4. Production of processed coffee grains per plant (A) and per orthotropic stem (B), and grain classification (large, medium, small and under-classified) (C) as response to the number of orthotropic stems per plant of Arabica coffee (Obatã), in low-altitude region. Means followed by the same letter do not differ from each other (Tukey test, $p \leq 0.05$ ). 
orthotropic stems in plants of Arabica coffee cultivated in low-altitude region (Figure 3). Plants with three and four vertical stems presented higher rates of net assimilation of $\mathrm{CO}_{2}$ (Figure 3A), lower stomatal openings (Figure 3B), lower transpiration rates (Figure $3 \mathrm{C}$ ) and lower sub-stomatal concentrations of $\mathrm{CO}_{2}$ (Figure 3D), while plants managed with one and two stems presented the opposite behavior for these parameters.

By the correlation analyses, it was observed strong relations between the net assimilation rate of $\mathrm{CO}_{2}(A)$ with leaf mass ratio $\left(r=0.97^{*}\right)$ and available leaf area per fruit mass $\left(r=0.95^{*}\right)$, indicating that higher proportions of mass in the plagiotropic branches being used to produce leaves, as well as larger leaf area available for fruit production, are directly correlated to higher photosynthetic rates.

The total chlorophyll content helps to support the results of gas exchanges in the plants grown with higher numbers of orthotropic stems, since the highest levels were obtained in plants with three and four stems, and lower for plants with only one stem (Figure $3 \mathrm{E}$ ). It is worth remembering that chlorophylls are the fundamental structures in the processes of capturing and transferring the light energy to be used by the photosynthetic process.

There was also a significant correlation between the total chlorophyll content and morphological characteristics, such as DEN $(r=0.97 *)$ and NPB $(r=0.99 * *)$. Thus, the increase in the number of plagiotropic branches in the coffee tree and in the densification of the foliage is directly related to increases in the chlorophyll content of their leaves.

\section{Production and classification of coffee grains}

Highest production of processed grains was observed from the plant managed with four orthotropic stems, followed by three stems and, with the lowest yields, one and two stems per plant (Figure 4A). Analyzing the production of grains per vertical stem made it possible to observe that greater quantity of coffee was obtained per stem when only one orthotropic stem (Figure 4B), and similar levels of production for the management with two, three and four stems per plant. However, considering the higher number of vertical stems per plant, the overall results per plant shift to the scenario showed in Figure 4A.

The yield per plant was positively and significantly correlated with the foliage density $\left(r=0.98^{*}\right)$, which supports the importance of the plant growth to achieve higher yields. In addition, this correlation allows the identification of the direct effect of a morphological characteristic over the productive capacity of the Arabica coffee in a low-altitude region, emphasizing the importance of the analysis of the direct and indirect effects of morphological characteristics as a criterion of evaluation of the productive potential (Martinez et al., 2007).

Regarding the physical classification of coffee grains based on size, a higher proportion of large grains and a lower proportion of small grains were observed due to the management with four branches, with no differentiation for medium and under-classified grains due to the changes in the number of orthotropic stems (Figure 4C). The increased proportion of larger grains in the management with four stems led to a decrease in the proportion of small grains, which is interesting for classification purposes. It should be noted that the standardization of grain mass is of paramount importance in the processes of drying and roasting, in order to leave the process more uniform, which can directly influence the final quality of the beverage (Rodrigues et al., 2014).

\section{Discussion}

The number of plagiotropic branches (Figure 1B) and the foliage density (Figure 1F) were the characteristics of the canopy with greater differentiation among means in response to the number of orthotropic stems per plant, giving a general idea of the canopy architecture of the plants with these stem managements. In order to obtain good levels of coffee yield, it is important to have a suitable number of plagiotropic branches, because they are the ones that support the reproductive structures. However, the isolated increase of these stems does not necessarily result in considerable increments of production (Pereira et al., 2011).

In this experiment, the number of plagiotropic branches correlated with the density of foliage, and this trait was related with the production of processed coffee by plant, making it possible to affirm that the higher yield occurred from the plants managed with four orthotropic stems was supported, at least partially, by the increase in foliage and number of productive branches of the plant.

As the increase in the number of orthotropic steams constitutes a form of densification in the plant itself, significant changes occurred in the leaf and fruit mass ratios (Figure 2C and 2D). Similarly, there was a change in the available leaf area per fruit mass (Figure 2E) from the plants managed with three and four orthotropic stems, where greater investments were observed in leaf structures, which is a behavior widely reported for Arabica coffee in densified conditions (Pereira et al., 2013; Rodrigues et al., 2016; Ronchi et al., 2016). It is worth mentioning that the greater foliage and denser canopy may have promoted the formation of a microclimate capable of attenuating the severity of some environmental stresses, such as high temperature and low relative air humidity (DaMatta et al., 2007).

The ecophysiology of growth and production of the Arabica coffee is favored by stability of temperature and the relative humidity of the air (DaMatta et al., 2007). The continuous exposure of coffee trees to elevated temperatures considerably affects the development of the plants (DaMatta and Ramalho, 2006), as it can be found in low-altitude regions, causing these regions to be classified as marginal or unfit for cultivation of this species of coffee. Thus, management with a greater number of orthotropic stems (e.g. four stems per plant) is able to promote a canopy densification and may generate a microclimate favorable to the development of Arabica coffee in these regions.

It is possible to manage the negative effects of the lower available leaf area to sustain the fruit development for plants managed with only one or two orthotropic stems by changing the crop density, both by the management of the number of stems or by changing the plant spacing itself. The densification of the crop promotes the investment in leaf structures, these organs being responsible for sustaining the photosynthetic apparatus (source of carbohydrates), making the plant less prone to metabolic impoverishment and less susceptible to high biennial effects (Chaves et al., 2012; 
Pereira et al., 2013; Rodrigues et al., 2016; Ronchi et al., 2016).

Plants managed with one and two orthotropic stems appear to have suffered some limitation in their gas exchange, resulting in lower photosynthetic rates (Figure 3). Even with higher concentrations of $\mathrm{CO}_{2}$ in the sub-stomatal chamber, greater degree of stomatal opening and higher transpiration flows, these plants presented lower net carbon assimilation (Figure 3A). This unbalance between the observed values for $A, \mathrm{~g}_{s}$ and $E$ indicates the existence of a possible biochemical limitation of photosynthesis (Flexas et al., 2012; Martins et al., 2014; DaMatta et al., 2008).

It is possible that this limitation to photosynthesis for the plants with one and two orthotropic stems is linked to the hydrolysis of RuBisCo enzyme and chlorophyll molecules, caused by the remobilization of its compounds to meet the demands of the fruit growth (stronger metabolic sink) (Reis et al., 2009; Chaves et al., 2012).

As plants with three or four orthotropic stems presented higher values of $A$ and smaller of $g_{s}$ and $E$, it is possible that these managements made the plants more efficient in using water for the photosynthetic processes, since they assimilate more carbon per unit of transpired water, based on intrinsic $\left(A / g_{s}\right)$ and instantaneous $(A / E)$ water use efficiencies.

The capacity to produce coffee (Figure 4A) can be considered as the overall result from the characteristics related to the vegetative development and metabolism of the plant, throughout the vegetative and reproductive cycle of the coffee tree. In this way, the highest yield obtained in the management with four orthotropic stems per plant could be considered as a response to the denser foliage (Figure 1F) and greater number of plagiotropic branches (Figure 1B), as well as the higher biomass proportions destined to organs that are sources of photo-assimilates (leaves) (Figure $2 \mathrm{C}$ and $2 \mathrm{E}$ ) and the highest photosynthetic rates (Figure $3 \mathrm{~A}$ ).

Based on the production per orthotropic stem (Figure 4B), it is possible to observe similar yields from the managements with two, three and four stems, demonstrating that the productive superiority in the management with four branches was also due to the total quantity of stems. In addition, the physical classification by size of coffee grains shows that the management with four stems favored the formation of grains classified as large, to the detriment of the proportion of grains considered as small (Figure 4C). This result helps to support the conclusion that more orthotropic stems may promote the densification of the canopy and is capable of providing improvements to the fruit development of the Arabica coffee plants in low-altitude region.

The superiority regarding morphological, physiological and growth characteristics observed for the plants cultivated with four and three orthotropic stems helps to sustain their fruit production in a more efficient and balanced way, which may also decrease the negative effects of bienniality and metabolic depletion of the plants (DaMatta, 2004; Chaves et al., 2012). Concomitantly, the positive response for growth, physiology and fruit production in said management indicates its potential use for the mitigation of stresses for the cultivation of Arabica coffee in low-altitude regions.

Overall, it can be observed that the plant densification, led by the management with more orthotropic stems per plant, acted as a mitigating method capable of favoring the cultivation of Arabica coffee in the studied region. This positive effect can be observed based on the several gains, specially observed in the comparison between plants cultivated with one and four stems. These results show the possibility of exploring alternative managements to enable the cultivation of Arabica coffee in regions previously classified as marginal or inept for the crop; and, among the options, the management of the number of orthotropic stems as densification strategy can be exploited for this purpose.

\section{Materials and Methods}

\section{Local conditions and experimental field}

The experiment was carried out in the Marilândia Experimental Farm (FEM) at the Instituto Capixaba de Pesquisa, Assistência Técnica e Extensão Rural (Incaper), in the municipality of Marilândia, in the northwestern region of the state of Espírito Santo, in the Southeast Region of Brazil. The altitude of the place is $124 \mathrm{~m}$ (classified as low-altitude for coffee crops, as it is under $500 \mathrm{~m}$ of elevation) and the topography of the region is wavy-rugged. The climate is tropical, with accumulated annual rainfall of $1,147 \mathrm{~mm}$ and average annual temperature of 24.2 ㅇ. .

The experimental field was implemented in 2011, using seedlings of Coffea arabica L. cv. Obatã IAC 1669-20 and 2.8 $\times 1.0 \mathrm{~m}$ of spacing $\left(3,571\right.$ plants ha $\left.{ }^{-1}\right)$, providing a population of plants within the recommended for Arabica coffee cultivation (Reis and Cunha, 2010). After 90 days of planting, the seedlings were bent to stimulate the emission of sprouts, maintaining the required number of shoots per plant according to the treatments.

The cultivar Obatã presents interesting characteristics to the cultivation in low-altitude regions, mainly due to the compact size of its canopy and good adaptation to densified systems (Rodrigues et al., 2016), also good levels of vigor and yield in regions of low altitude (Bergo et al., 2008).

\section{Experimental design}

The experiment was conducted with four treatments: one, two, three and four orthotropic stems per plant, corresponding to population of 3,$571 ; 7,143 ; 10,714$; and 14,286 orthotropic stems per hectare, respectively. The experimental design was a randomized block design, with eight blocks. Each experimental plot was composed of six plants, disposed in line, available for evaluations.

\section{Plant management}

The management of the fertilization was carried out according to the recommendations for the cultivation of Arabica coffee in the region, as well as phytosanitary treatments and cultural practices (Reis and Cunha, 2010). The supplementary irrigation was done using a drip system, during moments of high-water demand, concentrated in drought periods of summer.

The pruning management of the plants was carried out according to the recommendations for the programmed cycle system for Arabica coffee (Verdin Filho et al., 2016), with removal of plagiotropic branches which already produced $70 \%$ of their overall capacity. 


\section{Evaluated traits}

The evaluations occurred during the productive cycle of the second harvest (2014-2015), in plants presenting four years of age. Parameters of gas exchange, chlorophyll contents, canopy architecture, biomass production and allocation and crop yield were evaluated to characterize the plant development for the cycle.

In each experimental plot, a representative plant was selected and tagged for evaluation. In this plant, a representative orthotropic stem was selected and, in this stem, two plagiotropic branches from the medium part of the canopy were marked for gas exchange evaluations.

During the phenological stage of fruit granulation, the following gas exchange parameters were estimate: $\mathrm{CO}_{2}$ assimilation rate $\left(A, \mu \mathrm{mol} \mathrm{CO}_{2} \mathrm{~m}^{-2} \mathrm{~s}^{-1}\right)$, stomatal conductance $\left(\mathrm{g}_{\mathrm{s}}, \mathrm{mol} \mathrm{H} \mathrm{O} \mathrm{m}^{-2} \mathrm{~s}^{-1}\right)$, transpiration rate $\left(E, \mathrm{mmol} \mathrm{H}_{2} \mathrm{O} \mathrm{m}^{-2} \mathrm{~s}^{-1}\right)$ and sub-stomatal concentration of $\mathrm{CO}_{2}\left(\mathrm{Ci}, \mu \mathrm{mol} \mathrm{mol}{ }^{-1}\right)$. The measurements were made using an infrared gas analyzer (IRGA Licor 6400XT), on sunny days (without clouds); between 8 and 11 o'clock in the morning, taking by default a leaf between the third and fourth pairs of leaves from the apex of each marked plagiotropic branch. The photosynthetically active radiation was standardized by artificial saturating light at 1,000 $\mu \mathrm{mol}$ photons $\mathrm{m}^{-2} \mathrm{~s}^{-1}$ and the internal concentration of $\mathrm{CO}_{2}$ in the chamber at 420 ppm.

The chlorophyll content ( $\mathrm{CHL}$ ) was analyzed in the same tagged branches used for the evaluations of gas exchanges, using a portable chlorophyll-meter (ClorofiLOG, Falker FL1030). The measurements were also taken between 8 and $11 \mathrm{am}$ in the morning and on the same leaves used for the analysis of gas exchange.Characteristics related to the canopy architecture and development of plagiotropic branches were evaluated during the phenological stage of maturation on the plants of each experimental plot. The plant height $(\mathrm{PLH} ; \mathrm{m})$ and the length of the plagiotropic branches (LPB; $\mathrm{Cm}$ ) were measured with graded ruler. The total number of plagiotropic branches per plant (NPB) was counted. The insertion angle of the plagiotropic branches in the orthotropic stem (ANG; ) was obtained using a digital inclinometer. The leafage density (DEN, unit $\mathrm{m}^{-3}$ ) was obtained by the ratio between the number of leaves and the volume of the canopy of the plant. The unitary leaf area (ULA; $\mathrm{cm}^{2}$ ) was obtained by applying the linear dimensions method on all leaves on the tagged branch (Barros et al., 1973). Subsequently, the plagiotropic branches were cut, the plant organs were separated in paper bags and dried separately in laboratory oven, with forced air circulation at $65 \stackrel{\circ}{ } \circ( \pm 2 \circ C)$, until reaching constant weight. The dry mass of stem (DMS; g), leaves (DML; g) and fruits (DMF; g) were determined with precision electronic scale $(0.0001 \mathrm{~g})$. These variables were used to calculate the following characteristics: total dry mass of the plagiotropic branch (TDM; g), obtained by the sum of DMS, DML and DMF; stem mass ratio (SMR; \%), obtained by the relationship between DMS and TDM; leaf mass ratio (LMR; \%), as the ratio between DML and TDM; fruit mass ratio (FMR; \%), obtained by the relationship between DMF and TDM. The available leaf area was estimated as the ratio between the total leaf area and the mass of fruits of the plagiotropic branch (Leaf/Fruit; $\mathrm{cm}^{2} \mathrm{~g}^{-1}$ ).

The total mass of processed coffee per plant (CPP; g plant ${ }^{-1}$ ) was calculated based on the harvest of the fruits of the plants of each experimental plot. The fruits were dried and processed to obtain the final grain mass. The production of processed coffee per orthotropic stem (CPS; g stem $^{-1}$ ) was calculated by means of the plant yield and number of orthotropic stems per plant.

From each experimental plot, a sample of processed coffee (300 g) was collected, and the grains were submitted to physical analysis to determine the percentage of coffee retained in sieve classes (separation by flat shaped grain size), considering the classification of large grains (retained on sieves 17 and above), medium grains (retained on sieves between 15 and 16 sieves), small grains (retained on sieves 14 and below), and under-classified (not retained in any class of sieve).

\section{Statistical analyses}

The data were submitted to analyses of variance and, in the presence of significant differences, the Tukey criterion was used to compare the means from each treatment with one, two, three and four orthotropic stems per plant, at a $5 \%$ probability level. Pearson correlation coefficients (Steel et al., 1997) were estimated between the variables and studied by the t-test, at a level of 1 and $5 \%$ probability (** and *, respectively). Data analysis was performed using the GENES statistical analysis program (Cruz, 2013).

\section{Conclusion}

The management of Arabica coffee with higher number of orthotropic stems per plant (up to four stems) is able to increase the number of plagiotropic branches per plant, the leafage density, the leaf mass ratio of the plagiotropic branch, the available leaf area to sustain the development of fruits, the net assimilation of $\mathrm{CO}_{2}$, the crop yield, the proportion of larger grains, and is possibly able to cause deacceleration of the stem aging rate. The cultivation of Arabica coffee in low-altitude regions can be favored by the increase in the number of orthotropic stems per plant, as this management promotes the densification in the coffee canopy and, possibly, helps to generate a protective microclimate in the canopy of these plants, capable of enhance microclimate conditions at the canopy level and protecting the plants against some the of the environmental stresses.

\section{Acknowledgments}

The authors are grateful to Centro de Ciencias Agrárias e Engenharias of the Universidade Federal do Espírito Santo (CCAE/UFES) for providing access to the necessary facilities and laboratories. The authors are grateful to Instituto de Pesquisa, Assistência Técnica e Extensão Rural (INCAPER) for providing access to the experimental field. Moreover, the author T.V. Colodetti would also like to thank Fundação de Amparo à Pesquisa e Inovação do Espírito Santo (FAPES) for awarding doctoral scholarship.

\section{References}

Ainsworth EA, Rogers A (2007) The response of photosynthesis and stomatal conductance to rising $\left[\mathrm{CO}_{2}\right]$ : 
mechanisms and environmental interactions. Plant Cell Environ. 30: 258-270.

Alves JD, Paglis CM, Livramento DE, Linhares SSD, Becker FB, Mesquita AC (2011) Source sink manipulations in Coffea arabica L. and its effect on growth of shoots and root system. Ciênc Agrotec. 35: 956-964.

Assad ED, Pinto HS, Zullo JRJ, Ávila AMH (2004) Impacto das mudanças climáticas no zoneamento agroclimático do café no Brasil. Pesq Agropec Bras. 39: 1057-1064.

Barros RS, Maestri M, Vieira M, Braga Filho LJ (1973) Determinação de área de folhas do café (Coffea arabica $\mathrm{L}$. cv. 'Bourbon Amarelo'). Rev Ceres. 20(107): 44-52.

Bergo CL, Pereira RCA, Sales F (2008) Avaliação de genótipos de cafeeiros arábica e robusta no estado do Acre. Ciênc Agrotec. 32: 11-16.

Bunn C, Läderach P, Rivera OO, Kirschke D (2015) A bitter cup: climate change profile of global production of Arabica and Robusta coffee. Clim Change. 129(1-2): 89-101.

Camargo MBP (2010) The impact of climatic variability and climate change on arabica coffee crop in Brazil. Bragantia. 69: 239-247.

Chaves ARM, Martins SC, Batista KD, Celin EF, DaMatta FM (2012) Varying leaf-to-fruit ratios affect branch growth and dieback, with little to no effect on photosynthesis, carbohydrate or mineral pools, in different canopy positions of field-grown coffee trees. Environ Exper Bot. 77: 207-218.

Colodetti TV, Tomaz MA, Rodrigues WN, Verdin Filho AC, Cavatte PC, Reis EF (2018) Arquitetura da copa do cafeeiro arábica conduzido com diferentes números de ramos ortotrópicos. Rev Ceres. 65(5): 415-423.

Cruz CD (2013) GENES: a software package for analysis in experimental statistics and quantitative genetics. Acta Sci Agron. 35: 271-276.

DaMatta FM (2004) Ecophysiological constraints on the production of shaded and unshaded coffee: a review. Field Crop Res. 86: 99-114.

DaMatta FM, Cunha RL, Antunes WC, Martins SCV, Araujo WL, Fernie AR, Moraes GABK (2008) In field grown coffee trees source-sink manipulation alters photosynthetic rates, independently of carbon metabolism, via alterations in stomatal function. New Phytol. 178(2): 348-357.

DaMatta FM, Ramalho JDC (2006) Impacts of drought and temperature stress on cofeee physiology and production: a review. Braz J Plant Physiol. 18: 55-81.

DaMatta FM, Ronchi CP, Maestri M, Barros RS (2007) Ecophysiology of coffee growth and production. Braz J Plant Physiol. 19(4): 485-510.

Davis AP, Gole TW, Baena S, Moat J (2012) The impact of climate change on indigenous arabica coffee (Coffea arabica): Predicting future trends and identifying priorities. PLoS One. 7(11): 47-61.

Flexas J, Barbour MM, Brendel O, Cabrera HM, Carriquí M, Díaz-Espejo A, Douthe C, Dreyer E, Ferrio JP, Gago J, Gallé A, Galmés J, Kodama N, Medrano $H$, Niinemets Ü, Peguero-Pina JJ, Pou A, Ribas-Carbó $M$, Tomás $M$, Tosens T, Warren CR (2012) Mesophyll diffusion conductance to $\mathrm{CO}_{2}$ : an unappreciated central player in photosynthesis. Plant Sci. 193-194: 70-84.

Jaramillo J, Muchugue Vega FE, Davis AP, Borgemeister C (2011) Some like it hot: the influence and implications of climate change on coffee berry borer (Hypothenemus hampei) and coffee production in East Africa. PLoS One. 6:
24-52.

Lane A, Jarvis A (2007) Changes in climate will modify the geography of crop suitability: agricultural biodiversity can help with adaptation. J. SAT Agric. Res. 4(1): 1-12.

Martinez HEP, Augusto HS, Cruz CD, Pedrosa AW, Sampaio NF (2007) Crescimento vegetativo de cultivares de café (Coffea arabica L.) e sua correlação com a produção em espaçamentos adensados. Acta Sci Agron. 29: 481-489.

Martins SCV, Galmés J, Cavatte PC, Pereira LF, Ventrella MC, DaMatta FM (2014) Understanding the low photosynthetic rates of sun and shade coffee leaves: bridging the gap on the relative roles of hydraulic, diffusive and biochemical constraints to photosynthesis. PLoS One. 9(4): 1-10.

Pereira SP, Bartholo GF, Baliza DP, Sobreira FM, Guimarães RJ (2011) Crescimento, produtividade e bienalidade do cafeeiro em função do espaçamento de cultivo. Pesq Agropec Bras. 46: 152-160.

Pereira SP, Baliza DP, Santos MO, Alves JD, Guimarães RJ (2013) Influência do espaçamento de cultivo em duas épocas de poda nos teores caulinares de carboidratos em cafeeiros. Coffee Science. 8(4): 460-468.

Rahn E, Läderach P, Baca M, Cressy C, Schroth G, Malin D, Rikxoort HV, Shriver J (2013) Climate change adaptation, mitigation and livelihood benefits in coffee production: where are the synergies? Mitig Adapt Strat GI. 123: 01-19.

Reis AR, Favarin JL, Malavolta E, Lavres Junior J, Moraes MF (2009) Photosynthesis, Chlorophylls, and SPAD Readings in Coffee Leaves in Relation to Nitrogen Supply. Commun Soil Sci Plant Anal. 40: 1512-1528.

Reis PR, Cunha RL (2010) Café arábica: do plantio à colheita. U.R. EPAMIG SM, Lavras. 896p.

Rodrigues WP, Vieira HD, Barbosa DHSG, Sousa Filho GR, Partelli FL (2014) Agronomic performance of arabica coffee genotypes in northwest Rio de Janeiro State. Genet Mol Res. 13(3): 5664-5673.

Rodrigues WN, Tomaz MA, Ferrão MAG, Martins LD, Colodetti TV, Brinate SVB, Amaral JFT, Sobreira FM, Apostólico MA (2016) Biometry and diversity of Arabica coffee genotypes cultivated in a high density plant system. Genet Mol Res. 15(1): 1-12.

Ronchi CP, Almeida WL, Souza DS, Souza Júnior JM, Guerra AMNM, Pimenta PHC (2016) Morphophysiological plasticity of plagiotropic branches in response to change in the coffee plant spacing within rows. Semina: Ciênc. Agrár. 37: 381-389.

Sartori IA, Koller OC, Theisen S, Souza PVD, Bender RJ, Marodin GAB (2007) Efeito da poda, raleio de frutos e uso de fitorreguladores na produção de tangerineiras (Citrus deliciosa Tenore) cv. Montenegrina. Rev Bras Frutic. 29(1): 5-10.

Steel RGD, Torrie JH, Dickey D (1997) A Principles and procedures of statistics: a biometrical approach. McGrawHill Book, New York. 666p.

Titus A, Pereira GN (2008) Global warming in coffee plantations. Indian Coffee. 72: 19-24.

Verdin Filho AC, Volpi PS, Ferrão MAG, Ferrão RG, Mauri AL, Fonseca AFA, Tristão FA, Andrade Júnior S (2016) New management technology for arabica coffee: the cyclic pruning program for arabica coffee. Coffee Science. 11(4): 475-483. 